\title{
The Wellcome Tropical Research Laboratories in Khartoum (1903-1934): An Experiment in Development
}

\author{
AHMED AWAD ABDEL-HAMEED*
}

\section{I}

\section{The Start: Wellcome's Nile Cruise and his Association with the Sudan}

During the winter of 1900-1901, Henry Solomon Wellcome, the well-known drug manufacturer, happened to be in one of the first parties of European civilians to visit the Sudan after the battle of Omdurman. The trip left a very strong impression on Wellcome. The country was devastated by war, disease and famine, as his account of an island north of Khartoum illustrated. He found most of the inhabitants afflicted by a severe febrile illness:

It was very touching to see those natives who had come off from the shore to alleviate the suffering of their neighbours. This indicates in an agreeable manner how, in times of distress, the whole world is akin. I have been informed of instances where natives who were of enemy tribes came under truce to assist their neighbours when helplessly ill.

... One thing that impressed me greatly when I was at Khartoum was the possibility of making that city as healthy as New York, London or any other place. With its central location, it occurred to me that one could reach out in various directions from Khartoum, as a base, and collect materials and specimens for scientific investigation. ${ }^{1}$

In Khartoum his hosts were Sir Reginald Wingate, Governor General of the Sudan, and James Currie, Director of Education. He was shown plans for the Gordon Memorial College being constructed in memory of Charles Gordon. The generous donations from

*Professor Ahmed Awad Abdel-Hameed, Director, The Blue Nile Research and Training Institute, P.O. Box 101, Wad Medani, Sudan.

The author would like to express deep appreciation to Professor Martin Taylor of the London School of Hygiene and Tropical Medicine for his encouragement of this effort, his review of the manuscript and his valuable suggestions. Many thanks are also due to Mr John Symons of the Wellcome Institute for the History of Medicine whose help has been the starting point of this work. I would also like to extend my appreciation to Mrs Jane Hogan, Assistant Librarian at The Sudan Archives, University of Durham Library, where the bulk of the material for this study was found. Great help was also rendered by Ms Shirley Dixon of the Contemporary Medical Archives Centre and Ms Mary Gibson, Archivist at the London School of Hygiene and Tropical Medicine. This study was made possible by grants from the Wellcome Trust and the British Council.

\footnotetext{
${ }^{1}$ Gorgas Memorial Laboratory, Hearings before the Committee on Foreign Affairs, House of Representatives, Seventieth Congress, first session on H.R. 8128 to authorize a permanent annual appropriation for the maintenance and operation of the Gorgas Memorial Laboratory, Washington, United States Government Printing Office, 1928, pp. 32-52.
} 


\section{The Wellcome Tropical Research Laboratories in Khartoum}

the public enabled the establishment of a Gordon Memorial Fund as well as the erection of a magnificent brown-brick "college" building with Gothic features. However, the educational system in the Sudan was in its infancy, and primary education and basic industrial training were the first priority. Thus Currie suggested that, once the basic educational institutions had been housed, the unoccupied rooms in the Gordon College could be utilized for auxiliary institutions, including a small analytical laboratory, which, because of lack of funds, he hesitantly suggested "more in a spirit of expectation than as a practical proposal".2

After seeing these plans, Wellcome immediately offered to donate bacteriological and analytical laboratories to be part of the Gordon Memorial College provided that the authorities contributed to their upkeep. The condition of having to pay for the maintenance of the laboratories delayed acceptance of this generous offer until Lord Cromer, the British High Commissioner in Egypt, and the Financial Advisor of Egypt had both been consulted. Wingate was advised that Wellcome's gift amounted to about $£ 15,000$, and that the annual cost of running the laboratories was estimated at $E £ 800$ of which $E £ 400$ could be paid by the Gordon Memorial Fund and $\mathrm{E} f 400$ by the government $(\mathrm{E} f 1$ = one Egyptian Pound $=£ 1-0-6 d)$. Having secured approval of the authorities in Egypt, Wingate asked Wellcome to submit an official offer of his gift, to which Wellcome responded thus:

Sir,

I beg to offer for the acceptance of the Gordon Memorial College, Khartoum, a complete equipment for Chemical and Bacteriological Laboratories for Analytical and Research Work. The Laboratories would be designed:

- To promote technical education.

- To undertake the testing and assaying of agricultural, mineral and other substances of practical interest in the industrial development of the Sudan.

- To carry out such tests in connection with waters, food stuffs and sanitary matters as may be found desirable.

- To aid in criminal investigation in poisoning cases (which are so frequent in Sudan) by detecting and experimental determination of toxic agents, particularly those obscure potent substances employed by the natives.

- To study bacteriologically and physiologically tropical disorders especially the infective diseases of both man and beast peculiar to the Sudan, and to render assistance to the officers of health and the clinics of civil and military hospitals.

In order that the work of the laboratories may be thorough and efficient it is very desirable that the director shall be skilled and resourceful and be prepared to direct and carry out with zeal and energy all branches of work for which the laboratories are equipped, and a man who is willing to devote his life to the work of the Institution.

It is anticipated that the work of the laboratories will prove beneficial to both the European and native population. It is my desire that the laboratories be made as far as practicable self-supporting, by the charging of such reasonable fees as will aid in covering the cost of maintaining them. The

\footnotetext{
2 James Currie (ed.), The Gordon Memorial College at Khartoum, report and accounts (hereafter GMCK), Report for 1901, Khartoum, Department of Education, Sudan Government, 1902, p. 12. These reports were published annually (with the exception of 1914 and 1915 which were covered by a single volume). They were edited by the Director of
}

\begin{abstract}
Education and Principal of the GMCK. This post was held by James Currie until 1913; he was followed by J W Crowfoot, who was replaced by F W Winter in 1932. In these reports the section on the Wellcome Laboratories is written by the Director of WTRLK. Copies are held in the Library of the Agricultural Research Corporation, Wad Medani, Sudan.
\end{abstract}




\section{Ahmed Awad Abdel-Hameed}

only condition that I stipulate in making this offer is that the authorities are to maintain the laboratories and appoint and maintain an efficient Director and Staff for conducting the work.

In the event of your doing me the honour of accepting my offer I propose that the equipment shall be delivered either at Alexandria or Port Said, as you may prefer. ${ }^{3}$

In 1905 Wellcome was elected member of the Governing Body of the Gordon Memorial College, a position which he held for the rest of his life. Yet, Wellcome's interest in the Sudan was not limited to establishing a scientific base for its future development: he was equally fascinated by exploring the past of this land and its people. This led him to establish an extensive archaeological excavation project in Jebel Moya in central Sudan that continued from 1910 until after his death. It was primarily a philanthropic activity, providing employment and social development for the inhabitants of the area.

Thus Wellcome's association with the Sudan had many facets. In the present paper I intend to cover Wellcome's Tropical Research Laboratories in Khartoum as a milestone in the development of the Sudan and tropical medicine. The story of these laboratories is closely interwoven with the lives of its three successive directors: Andrew Balfour, Albert Chalmers, and Robert Archibald. Each one represents a generation in tropical medicine and a distinct phase through which the laboratories have passed. Thus the story of the Wellcome Tropical Research Laboratories can conveniently be told through the biographies of its three directors.

\section{II}

\section{Andrew Balfour of Khartoum}

... I propose to begin by appointing as good a bacteriologist as can be secured. Much depends on the stamp of the man that, with our limited means, is obtainable. ${ }^{4}$

As this quotation shows, Currie shared Wellcome's conviction that the success of the laboratories would depend to a large extent on its director. The man chosen happened to be a young Scotsman, Dr Andrew Balfour.

Andrew Balfour was a native of Edinburgh, born on 21 March 1873, the son of Dr T A $\mathrm{G}$ Balfour, a well-known practitioner in that city. At an early age Balfour established a reputation as a man of many talents. During his student days he was a six-foot, fourteenstone boxer and rugby player who appeared for Scotland against England on many occasions. He was also a novelist. His first novel By stroke of sword, published in 1897, was a story of romance and adventure on the high seas and in Spanish America, and The golden kingdom (1903) was based on his scientific knowledge of sleeping sickness. After graduating MB, CM at Edinburgh in 1894, he joined his father's medical practice, but soon realized that he had more inclination for public health than for clinical practice. Thus he entered Cambridge University in $\mathbf{1 8 8 5}$ and obtained the Diploma in Public Health in 1887 , followed by an MD for which he was awarded a gold medal for outstanding research work. Then he obtained a BSc in public health from Edinburgh. Balfour's first tropical experience came in the South African war as a civilian surgeon in charge of a

${ }^{3}$ Gordon Memorial College Board of Trustees, Minutes Book, The Sudan Archives, Durham

${ }^{4}$ Currie (ed.), GMCK, Report for 1901, p. 12. University (hereafter SAD) 572/5/61. 


\section{The Wellcome Tropical Research Laboratories in Khartoum}

typhoid camp in Pretoria during 1900-1901. This memorable experience left its stamp on his future career:

There one saw the disease at its worst, witnessed wretched, stuporous patients in stinking Khaki taken from trains and ambulance wagons, heard the droning buzz of accompanying cohorts of filthy flies, saw peeling and crusting lips, teeth coated with sores, and tongues dry as those of parrots. One witnessed, all too frequently, the horror of excessive meteorism, the shock of haemorrhage, the tragedy of perforation ... 5

From this situation, Balfour emerged with the South African Medal and three clasps. In September 1902, he was appointed first Director of the Wellcome Laboratories in Khartoum. He started his work in London by meeting Henry Wellcome and inspecting the furniture and equipment purchased for the Khartoum laboratories. He was impressed by the high quality and by the excellent furniture made of English oak and Indian teak baked for several months to withstand the hot climate.

One of Wellcome's valuable business assets was his flair for publicity and for creating an acceptable public image, which he missed no chance in presenting to the world at large. On 8 December 1902, he celebrated Balfour's departure to Khartoum with a dinner in the Prince's Hall, Piccadilly, London, to which he invited celebrities in politics, medicine, science, and business, as well as his close friend Sir Henry Stanley, the famous explorer, and, of course, the Press. ${ }^{6}$ It was a chance to introduce the young Balfour to people of influence and at the same time to give them a chance to say what they expected of him. Wellcome spoke of how appalled he was by the conditions in the Sudan and of his belief that by donating the laboratories he was offering a means of improving the health and well-being of the inhabitants of the country and of mankind in general. At the same time, the laboratories would provide a valuable opportunity for someone pursuing a research career. Balfour responded by thanking Henry Wellcome. He expressed his anticipation of hard and troublesome work in Khartoum but he promised to do his best so that "even a Scotsman could do no more". For Henry Stanley this dinner was his last public appearance. He gave a moving speech on his memories of African exploration and how he thought at one time that the "plagues of the Dark Continent" would never make it habitable. He was gratified to see such a laboratory being erected. Dr Patrick Manson (then at the height of his fame) commended the intelligent perception of Wellcome in establishing such a laboratory at a time when Africa was undergoing an "enormous pathological revolution". He expressed confidence in the abilities of Dr Balfour but he warned that people should not be too impatient to see the results of his work.

\section{Establishing the Khartoum Laboratories}

Balfour arrived in Cairo on 24 December 1902 and remained there for three weeks while he visited health institutions in Egypt and recruited John Newlove as Laboratory Assistant. He then proceeded to Khartoum, arriving on 22 January 1903. The Gordon Memorial College had been officially opened on 8 November 1902, but the fitting of the

\footnotetext{
5 A Balfour, War against tropical disease, 2nd ed., London, Published for the Wellcome Bureau of Scientific Research by Baillière, Tindall \& Cox, 1921, p. 72.
}

${ }^{6}$ A Balfour, Album of newspaper cuttings, $\mathrm{SAD} / 14 / 4$. 


\section{Ahmed Awad Abdel-Hameed}

furniture and equipment into the laboratories awaited his arrival. The lack of skilled labour and the long distance from suppliers caused delays. Nevertheless, on 1 February 1903 (eight days after his arrival) Balfour started work examining pathological material from patients and plants. For the first year his staff consisted only of two Sudanese laboratory attendants and Newlove, who arrived on 1 April 1903. The laboratory buildings comprised a suite of five rooms: a kitchen for preparation of media, separate bacteriological and chemical rooms, a chamber specially prepared as a photographic dark room, a cold storage room and a museum room. Adjoining these were the Director's Office and an Economic and General Museum. Balfour was soon able to recruit a team of scientists: Dr William Beam, Research Chemist, joined in 1904, and Harold King, Entomologist, in 1906; later arrivals were James Thompson, Senior Assistant Chemist, and J Goodson, Assistant Chemist; Captain Robert Archibald, RAMC, Pathologist, joined in 1908, and Captain W B Fry, RAMC, Protozoologist, in 1910 (replaced by Captain W R O'Farrell, RAMC, in 1912). Newlove, who had started as Laboratory Assistant, became Sanitary Inspector in 1906; two other laboratory assistants, George Buchanan and Alexander Marshall, were also recruited. In 1910 the title of the laboratories was officially changed, at the request of Henry Wellcome, from 'The Wellcome Research Laboratories' to 'The Wellcome Tropical Research Laboratories' (WTRLK), the name which had in fact been used in the laboratory reports published by Wellcome since $1904 .^{7}$

\section{Hunting for Mosquitoes}

At the time of Balfour's arrival in Khartoum, Ross had just been awarded the Nobel Prize. Accounts of the work of his Mosquito Brigades in Sierra Leone, Lagos, the Gold Coast and Ismailia (1899-1902) were published and widely distributed in the tropics. It was no wonder that Ross enthusiasts were then eager to see mosquito brigades working in the Sudan. In May 1903, Colonel M Talbot, RE, who was Director of the Survey Department in the Sudan, wrote to the Governor General about his concerns:

Do you think enough is being done to worry the mosquitoes? I think most persons are still blind or deaf to the beauties of the mosquito theory and I don't think that the medical officers can do much unless cordially supported by laity. ... How much does fever cost us a year and how much have we spent in trying to prevent it, except in the matter of building ... This zeal on my part is due partly to the discovery that doctors don't hunt for mosquitoes as part of their regular work and secondly to my being a brand new convert to Ross's opinions from reading his books while up the White Nile. It is the hope that he may convert them in the same way as he has converted me, that makes me wish to see his pamphlets scattered broadcast in the Sudan. ${ }^{8}$

Balfour soon received his invitation of "cordial support" to which he responded with an enthusiasm which initiated one of the most effective mosquito control programmes of the period. A small mosquito brigade was formed on the lines suggested by Ross consisting

\footnotetext{
7 A Balfour (ed.), First report of the Wellcome Tropical Research Laboratories at the Gordon Memorial College, Khartoum, London, Baillière, Tindall \& Cox, and Sudan Government, Department of Education, 1904; A Balfour (ed.), Fourth report of the Wellcome Tropical Research Laboratories at the
}

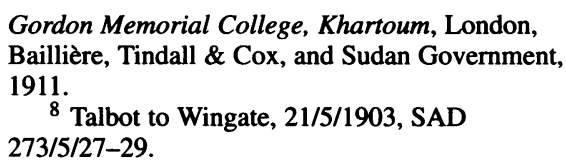




\section{The Wellcome Tropical Research Laboratories in Khartoum}

of Newlove and two Sudanese workers. Every morning the brigade visited and examined systematically all water collections in the town, beginning on the river front, and working day by day till the whole town was covered. In the afternoon the men again went on their rounds, the water collections were reinspected and any found to be infected were thoroughly oiled. Gradually the number of workers was increased, and by 1909 there were seven Sudanese inspectors controlled by two British sanitary inspectors, one of them responsible for Khartoum, the other for Khartoum North, while the steamers and boats were looked after by a special Sudanese inspector. The town of Omdurman was never included by Balfour in these activities, perhaps because funds for mosquito control were meagre: less than $£ 100$ per year. Regulations to control the breeding of mosquitoes were formulated and strictly implemented in houses and on steamers as well as in agricultural schemes. These measures proved their effectiveness for, by 1905, people in Khartoum were able, for the first time, to sleep without bed nets. ${ }^{9}$ In his Fourth report Balfour related an anecdote to show how well the control programme worked:

One morning a female Stegomyia had the impertinence to bite me on the hand in my office at the Gordon College. Next day the insult was repeated. I was much surprised, for we are far from the dockyard, which is, as a rule, the only place where these mosquitoes are now to be found, and there only very occasionally.

Sending at once for an Inspector, I asked him to make a careful search in the grounds of the building. He did so and he reported that he found nothing. He then expressed a wish to inspect the laboratories. I said "By all means, but you'll find nothing there." I followed him into our bacteriological room, and, with unerring instinct, he made for a "burma" or red earthenware vessel upon a stand. "Oh," I remarked, "you need not trouble to look there, it's always empty." "Not of mosquitoes, doctor," was his reply, and then gentlemen, the murder was out. There were soda-water bottles lying in water to keep them cool in that "burma," and the water had not been changed for days, and was swarming with a lively brood of Stegomyia "wrigglers" and nymphs, while new-born "imagines" were clinging to its sides prior to their first flight upon the blood quest. The culprit was a clerk, who, against orders, had adopted this method of storing his drinks, and had taken no precaution against mosquito invasion. I fined him, but I had also to fine myself, for I was primarily responsible, and I do not doubt that in the Inspectors' mess there was much joy over my delinquency. ${ }^{10}$

Balfour's success in eradicating mosquitoes was such that when Theodore Roosevelt, the former President of the United States, visited Khartoum, the Daily Mail (March 1910) commented that he was "greatly interested in the research laboratories where tropical diseases are investigated, and expressed his admiration for the work of Dr Balfour, who banished the malarial mosquito from Khartoum".

\section{Balfour's "Sanitary Tyranny"}

When Balfour became Director of the WTRLK, the government departments in the Sudan were just being structured. There were considerable overlaps and gaps in the distribution of responsibilities among government institutions. In the absence of clear official policies and regulations, the running of the government machinery depended to a

${ }^{9}$ H C Squires, The Sudan medical services: an experiment in social medicine, London, Heinemann Medical Books, 1958.
10 Balfour (ed.), Fourth report, 1911, op. cit., note 7 above, p. 253. 


\section{Ahmed Awad Abdel-Hameed}

great extent on personal relationships. As Governor General, Wingate had absolute power, referring only in major matters to the British representative in Egypt, Lord Cromer. Balfour took full advantage of this situation. Through his close relationship with Wingate he was able to extend his influence to new areas thereby causing friction with other government officials. Balfour refused to allow the Wellcome Laboratories to be incorporated in the medical department after it was formed in 1904 but he assumed the post of Medical Officer of Health of Khartoum under the authority of Khartoum Province. However, he restricted his sanitary activities to Khartoum and Khartoum North, continuing to ignore completely the town of Omdurman on the west bank of the White Nile although it fell within the boundaries of Khartoum Province. ${ }^{11}$ Gradually, Balfour established what he proudly called a "sanitary tyranny", enforced through his four British sanitary inspectors whom he described as a "mounted force" because they were in the saddle most of the time. Apart from mosquito work, their responsibilities included running the conservancy system, registration of milk vendors and frequent checking of milk by chemical and bacteriological tests, refuse destruction, control of mineral water factories, inspection of markets and slaughter houses, house-to-house inspections, regulation of "noxious trades", poisoning stray dogs, attending prosecutions and giving evidence. By supervising filtration and constant bacteriological checks, Balfour provided the population of Khartoum with exceptionally pure water supplies from bore holes in Burri village near Khartoum and from the Blue Nile. Some of the measures he employed were extreme, and attracted criticism from other doctors such as that expressed by $\mathrm{J}$ B Christopherson, RAMC, Director of the Medical Department, who wrote to a friend:

I feel that I am doing the Collar [sic] work and that someone else is doing the parade work ... Well what happened was this! B has been lately terrifying everybody on account of a case or two of Cerebro Spinal meningitis [sic] which occurred here (we have it every year in one part of the Sudan or another). ... Balfour was writing reports, isolating battalions-spraying with antiseptic lotions hundreds of soldiers' noses and throats daily-looking down microscopes and looking up the records of other outbreaks-surrounding houses with gaffirs [guards] (whereon of course all the patients' friends ran away and would have spread it if it had been possible). The 4 sanitary inspectors kept galloping up to the patient's house (where there was one) to inquire how it was getting on and then galloped to the Gordon College to report to Balfour and then galloped back to the mudiria [governor's office] to write a report and then when one patient died-the $\mathrm{MOH}$ and assistant MOH, 4 Sanitary Inspectors[,] most of the Conservancy officials - the Sub-Mamour [administrative assistant] and a posse of Police and Gaffirs pulled down the house and burnt all valuable furniture and fittings usually found in a Soudanese [sic] gentleman's house and his clothes and marched off [the] patient's family and relatives for 4 generations back and neighbours to the old Khartoum jail and kept them-hugely delighted-for 10 days - at Government expense and nothing happened ... ${ }^{12}$

Although Balfour in the main used his "mounted force" for ground operations, under certain circumstances he resorted to the Floating Laboratory (described below) as a naval unit:

A certain company took up the question of converting the "Sudd", that matted growth of papyrus, vossia grass, reeds and bushes, into fuel, and sent a steamer, an old ferry-boat, South to experiment.

${ }^{11}$ Squires, op. cit., note 9 above.

12 Christopherson to Sa'id Pasha Shouair, Pre 1914, SAD 494/11/2-7. 


\section{The Wellcome Tropical Research Laboratories in Khartoum}

One morning our inspector at Khartoum North rang me up in alarm and well nigh despair. The ferryboat had returned full of "Sudd" and full also of mosquitoes, which were flying ashore in a black cloud, seeking whom they might devour. Prompt action was necessary. The inspector was ordered to engage special men on the spot, take the laboratory steamer, and tow the offending craft down the Nile to the lonely and sandy Tuti Island where the cargo was discharged and the holds oiled. It was a cheerful task. The ferry-boat had no helm and she and the steamer went waltzing down stream, while the unfortunate experimenter tore his head in despair, and eventually invaded my sanctum to find out how he really stood, and to learn the enormity of his methods. ${ }^{13}$

It remains undisputed that, under Balfour, Khartoum enjoyed an exceptionally high standard of sanitation. By 1910, he was able to tell the Conference of the Sanitary Inspectors' Association in London: "So far as communicable diseases go, I doubt if a healthier city than Khartoum exists in Africa at the present moment."14 It is true that Balfour restricted his efforts to Khartoum and Khartoum North, yet his work set a standard for the whole country.

\section{Research Under Balfour}

In contrast to sanitary work, Balfour viewed routine clinical work as an unnecessary burden. He welcomed pathological specimens only if they fitted into the Pathology Museum or were relevant to research, which he believed was the "true function" of the laboratories. Balfour did not make any scientific discoveries of lasting value during his stay in Khartoum. In this respect he faced many obstacles. Sanitary and administrative work took up much of his time, and his professional isolation at that distance from well established scientific institutions in Europe was another disadvantage. Balfour's own research suffered many set-backs. In 1908 a fire at the laboratories destroyed valuable research material on sleeping sickness, all the office papers for five years, the bacteriology laboratory and manuscripts of which he had kept no duplicates. Wellcome provided new equipment and refurbished the buildings very quickly, but the research material collected over years was difficult to replace. Balfour also had difficulties in breeding and maintaining laboratory animals. On his return from annual leave in 1909 he found that all the guinea-pigs he kept for trypanosomiasis research had died because of inadequate feeding. Even his extensive mosquito work was done on an empirical basis and simply confirmed Ross's views without producing new discoveries. Thus, in spite of the apparent effectiveness of the mosquito work in Khartoum, Balfour could not provide Ross with the scientific data which the latter needed for his statistical models for predicting outbreaks of malaria. Of all the reviews published on Balfour's research work in Khartoum, that in the British Medical Journal (15 June 1912) gave the most unbiased and fair judgement:

It is with some trepidation that one turns for review the pages of a report such as the Fourth Report of the Wellcome Tropical Research Laboratories. One feels almost unconsciously that the ground is delicate, and that allowances of some kind or another have to be made. In the first place, it cannot be ignored that Khartoum is not London and that the conditions of research are essentially different in the two places. At the same time, it must not be forgotten that almost all the greatest discoveries in tropical medicine have been done on the spot, so to speak, although it is true that

13 Balfour (ed.), Fourth report, 1911, op. cit., note $\quad{ }^{14}$ Ibid., p. 262. 7 above, p. $253-4$. 


\section{Ahmed Awad Abdel-Hameed}

many of them required the work of European authorities to interpret their intrinsic importance and their bearings on science and medicine in general. Partly on this latter account, it is, unfortunately, not an uncommon habit of these stay-at-home savants to belittle the efforts of their more enterprising, if in many cases, it must be admitted, less able scientific brethren.

Once the research base at Khartoum was established, a need was felt to reach out to the provinces. Travel by camel and mules was onerous and dangerous. It was difficult to perform scientific work in a dusty tent using unstable tables or boxes for benches. To overcome these problems, Balfour produced one of the most novel ideas of the WTRLK, a floating laboratory. After the Sudan Government provided a two-decked barge, Wellcome fitted the vessel with a complete laboratory, comprising two long benches, with water supply from a carbon filter, water taps and sinks and a set of equipment and glassware. At first the laboratory was towed by regular post boats but later a launch with living quarters was acquired and called the Culex. The first scientist to use the laboratory was Dr C M Wenyon, protozoologist at the London School of Tropical Medicine. Under his charge, the laboratory started in April 1907 on a maiden trip up the White Nile. Wenyon later reported that it "reminded one more of a laboratory at home than the accommodation one would expect to find on one of the upper tributaries of the Nile in some remote corner of the Sudan." 15

The laboratory soon proved its value in enabling researchers to collect data from remote areas for ethnological, pathological, parasitological and entomological studies.

\section{Reports of the Wellcome Tropical Research Laboratories in Khartoum}

One of Henry Wellcome's favourite methods of indirect advertising for his firm was the free distribution of drug samples in "Medicine Chests". The list of recipients included Edward VII, George V, Gladstone, President Roosevelt and Sir Henry Stanley. Wellcome's chests went to the North and South Poles, to Everest and on the flights of pioneer aviators. Each time one was presented, he made sure that everyone knew about it. ${ }^{16}$ Wellcome, likewise used his skills as a publicist to draw attention to the Khartoum Laboratories named after him. Late in 1904 the first of a series of reports by the Wellcome Research Laboratories in Khartoum was published at Wellcome's expense. It covered the period between 1 February 1903 and 1 February 1904. The quality of illustrations and coloured plates shows that Wellcome spared no expense in the production of these reports. He personally prepared the list of recipients of complimentary copies, later supplemented by others from Wingate, Currie and Balfour. Leather-bound copies were sent to HM the King, the Czar of Russia and the Emperors of Germany and of Japan, among others. Another exhaustive list included more than 1,200 prominent people ranging from ambassadors of foreign countries to businessmen in China, as well as editors of 181 journals and newspapers, and 67 libraries of universities and societies in the United States

\footnotetext{
${ }^{15} \mathrm{C}$ M Wenyon, 'Report of travelling pathologist and protozoologist', in A Balfour (ed.), Third report of the Wellcome Tropical Research Laboratories at the Gordon Memorial College, Khartoum, London, Baillière, Tindall \& Cox, and Sudan Government,
}

\footnotetext{
Department of Education, 1908, pp. 121-68, p. 121.

${ }^{16} \mathrm{H}$ Turner, Henry Wellcome: the man, his collection and legacy, London, The Wellcome Trust and Heinemann, 1980.
} 
and Britain. ${ }^{17}$ Complimentary copies were sent from Wellcome's Office at Snow Hill with a note: "On behalf of the Department of Education of the Sudan Government".

Apparently Wellcome's philanthropy was not well known outside the English-speaking world: before forwarding the report to the Czar, the Russian envoy wrote inquiring why a report by the Sudan Department of Education should be sent by the firm of Mr Wellcome. He was told the whole story, and that was perhaps why he was sent the complimentary copy in the first place. After the success of the First report, the Second report was published in 1906, and the Third report in 1908, together with a supplement by A Balfour and R G Archibald: Review of some of the more recent advances in tropical medicine. With each new issue the size grew. For this reason the Fourth report, which appeared in 1911, was issued in two volumes, A-Medical and B-General Science, again with a supplement. In those years, the Sudan enjoyed a happy relationship with the British press, Balfour and Wellcome judiciously cultivating public opinion, and the reports were well reviewed. On receiving the Second report, the Daily Mail wrote (25 September 1906):

"All Central Africa is going to be made perfectly habitable for the white man. Its agricultural, industrial, and commercial resources will become available. The Niles and their tributaries will teem with the commerce of a numerous and happy people". Mr Henry S. Wellcome, who made this statement to a representative of the "Daily Mail", is the well known American chemist and bacteriologist of Snow Hill buildings, Holborn Viaduct. Six years ago Mr Wellcome went out to the Sudan. "Disease was rampant," he said. "People, livestock, and growing crops were perishing almost without a finger lifted to stay the calamity. I was granted permission to found what have been named the "Wellcome Research Laboratories"'.

With the issue of the Fourth report, a pamphlet was distributed, which contained a price list for the publications of the Wellcome Tropical Research Laboratories and the following announcement:

The great cost of production of these Reports, especially in their present voluminous dimensions, necessitates making a charge for them now and henceforth. The price fixed is as moderate as is consistent with the cost of publication, and any profit made will be devoted to a special fund towards the cost of future publications of the Laboratories. ${ }^{18}$

\section{The Laboratories Come of Age}

The work of Balfour as MOH for Khartoum was very demanding. At times he had to wake up at 3 a.m. to check latrine bucket collectors, he had to visit the homes of patients with suspected communicable diseases, and to supervise all aspects of sanitation in a town under construction in the tropics. Moreover, he had to report on routine laboratory investigations and conduct research. Even during the annual leave that every British official had to take, Balfour worked very hard on the production of the laboratory reports. He did this with the obsession of a perfectionist until exhaustion made him call a halt, but he was soon back again, writing to Wingate:

\footnotetext{
17 Wellcome Tropical Research Laboratories records, in the Wellcome Archives, Contemporary Medical Archives Centre (hereafter CMAC), Wellcome Institute, London. (These archives are in the process of being catalogued so full references are not available).
}

18 A copy is held in the Library of the Agricultural Research Corporation, Wad Medani, Sudan. The quotation appears on p. 1. 


\section{Ahmed Awad Abdel-Hameed}

I am "sound as a bell" \& have merely been suffering from nerve strain. I feel just about all right again and am busy with the Report. It is being pushed forward as rapidly as possible but in some ways it's just as well I arrived on the scene for there were all kinds of delays owing to difficulties about illustrations. I regret that it has been so long in appearing but it runs to about 230 pages and contains 20 coloured plates besides numerous figures etc. ${ }^{19}$

By 1909, Balfour started to suffer severely from the strain of work and at the same time he began to feel that the laboratories had outgrown the budgetary allowances allotted them by the government. Although he had the sympathy of Wellcome and Wingate, it was apparent that the continued budget deficit did not allow the government to meet all Balfour's ambitious demands. He was trying to address these problems when he wrote to Wingate:

The routine work has very greatly increased[.] I felt there was no use striving to accomplish the impossible. As one example take the research on trypanosomiasis, which has had to be abandoned for the present \& yet is of great importance especially in view of the news from the Bahr el-Ghazal. As a matter of fact the research work tends to get more \& more " scrappy", a fact I deplore but am powerless to remedy at present without curtailing the general usefulness of the laboratories \& that would be a sad pity. It may be, one has not so much energy as of yore, I believe this is true, but one gets older \& the Sudan is a trying place for scientific research. We have established a certain standard of work I should be very sorry depart from it. It was very kind of you to send me $\mathrm{Mr}$ Wellcome's letter and your reply thereto. Apart from his eulogies, what Mr Wellcome says is very true $\&$ as I told you the finance people have not the vaguest notion of what scientific work means or what it entails. I can furnish proofs of this statement if desired. It is perhaps unreasonable to expect them to possess such knowledge but I feel they might have more confidence in the assurances given them as to the paucity of funds \& staff. ... Take the laboratories in the Philippine Islands, the Malay Federated States etc. and it will be seen how we lag behind. We have grown and require to be fed $\&$ the food for an infant will not serve an adult. ${ }^{20}$

Besides these constraints to his professional aspirations, Balfour had good reason to believe that if he continued living in the Sudan his health would be badly affected. He suffered from asthma and the dusty weather of Khartoum brought on bad attacks. In addition, he happened to prick his finger with a contaminated needle while inoculating a rabbit's brain and he had to go to Cairo for a course of anti-rabies vaccination. Thus Balfour started to have second thoughts about his work in the Sudan.

During his directorship of the WTRLK, Balfour had gained the admiration and confidence of Wellcome, who understood his ambitions and frustrations and supported his appeals to the government for more budgetary allowances. Eventually, Wellcome offered him the position of Director-in-Chief of the Wellcome Bureau of Scientific Research which he intended to establish in London in 1913. Balfour accepted and submitted his resignation. Before leaving, his last task was to submit to the Sudan Government a master plan for future development of the laboratories, including buildings, staff, and research policies, stressing integration with agricultural and veterinary workers and taking into account the experience he acquired during his ten years in Khartoum. He reiterated his strong conviction of the wisdom of spending more on sanitation and research, citing an example from India:

19 Balfour to Wingate, 24/5/1906, SAD $278 / 5 / 139$.
20 Balfour to Wingate, 28/10/1909, SAD 289/1/57-59. 


\section{The Wellcome Tropical Research Laboratories in Khartoum}

"During the preceding two years", says the recent Blue Book on the progress of Sanitary Measures in India, "the imperial grants for sanitation have aggregated 181 1/2 lakhs $(£ 1,210,000)$

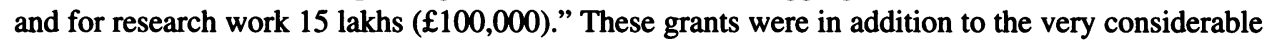
sums expended by local governments, municipalities and district boards. India will reap her reward, and it will be a rich one, for, after much tribulation, it has at last been recognized that both sanitary progress and clinical work are dependent upon organized research, and, once this great truth is realized, half the battle is won. In some respects it may fairly be claimed that the Sudan, thanks largely to the generosity of Mr Wellcome, has led the way. It is, however, imperative, if not to keep the lead, at least to keep abreast of the developments elsewhere. ${ }^{21}$

From his summer resort in Erkowit Wingate wrote him an emotional farewell: "I cannot tell you how much I regret, as the time approaches, your impending departure from us. It is when you are actually gone that we shall feel your loss most acutely, ...". 22

In May 1913, Balfour left Khartoum, a town that he had helped to build and in which he had established his career in tropical medicine. His association with the place was so close that his name became linked to it and journals like the Lancet referred to him as "Andrew Balfour of Khartoum".

\section{Mission Accomplished}

At the time of Balfour's departure the WTRLK were well established at an international level. Balfour started the laboratories with an annual budget of about $£ 800$, when he left this had increased to $£ 6,460$, a considerable amount of money for the Sudan, which was still dependent on the bounty of Egypt to cover its annual budget deficit. It is doubtful if any other person without Balfour's influence and administrative skills could have erected such an institution under such circumstances. After leaving Khartoum, he pursued a brilliant career in tropical medicine in which he held many distinguished posts and received many honours. In 1923 he was appointed the first Director of the London School of Hygiene and Tropical Medicine. He was elected President of the Royal Society of Tropical Medicine and Hygiene in 1925, and in 1930 he was knighted. However, in spite of all these commitments, Balfour never ceased to be one of the most active members of the Governing Body of the Gordon College in London, which he joined on his resignation from the WTRLK and continued to serve until his death in 1931.

21 Balfour to Director of Education, 11/3/1913,

22 Wingate to Balfour, 27/3/1913, SAD 185/3/11. SAD $185 / 3 / 50-55$. 
III

\title{
Albert J Chalmers: the Agonies of the First World War
}

\author{
Long, long the barren years; \\ Long, long, O God, hast Thou \\ Appointed for our tears \\ This term of exile. ${ }^{23}$
}

Albert John Chalmers was born in Manchester in 1870. Qualifying in 1890 at University College, Liverpool, he held the Holt Fellowship before joining the West African Medical Service, in which he served for four years on the Gold Coast, and in 1900 he received a medal and clasp of the Ashanti Expedition. He left for Ceylon in 1901 where he worked for the next ten years as registrar at Colombo Medical College. In 1911 he was awarded the Coronation medal. After a period of service with the Pellagra Field Commission he was appointed in 1913 Director of the Wellcome Tropical Research Laboratories in Khartoum. By then he was a well known name in tropical medicine. While in Colombo he co-authored with Aldo Castellani the Manual of tropical medicine, the first edition of which appeared in 1910 and was described by F H Garrison as "the best modern book on tropical medicine". 24

\section{A New Role for the Laboratories}

It has been suggested that Manson and Ross reflected two rival traditions associated with two different aspects of the medical profession. Manson was representative of a new, reductionist and research-based "laboratory medicine", whereas Ross acted within the older preventive and sanitary tradition. If we apply such a distinction to directors of the WTRLK then Chalmers would fit in the school of Manson whereas Balfour tended to follow the tradition of Ross. Moreover, Balfour's tropical medicine career, like that of Ross, started with military service and a strong public health orientation as demanded by imperial expansion. Chalmers, on the other hand, represented a second generation of tropical medicine workers, attracted to tropical medicine primarily as a fertile field for scientific research and academic excellence. Thus it was not surprising that Chalmers made major changes in the structure and management of the laboratories. He explained that "The whole laboratory was recast to enable work on human diseases \& inoculations of animals to be performed \& special chemicals were obtained to form media for the growth of the germs". 25

The laboratory was gradually transformed into an institute for tropical medicine in the strict sense, leaving for a while the integrated multi-disciplinary research policy. Reginald Massey had been appointed by Balfour as "Economic Botanist" to study poisonous plants and problems of Acacia and cotton, and to work on a botanical garden. These were not

23 From In exile, by Ronald Ross, quoted in $\mathrm{W}$ Osler, 'The nation and the tropics', Lancet, 1909: ii, 1401-6, p. 1402.

${ }^{24} \mathrm{~F}$ H Garrison, An introduction to the history of medicine, 4th edn, Philadelphia and London, W B Saunders Company, 1929.
25 Chalmers to Wingate 25/2/1915, SAD $194 / 2 / 171$. Chalmers made the same statement using slightly different wording in GMCK, Report for 1913, p. 18 


\section{The Wellcome Tropical Research Laboratories in Khartoum}

within the sphere of Chalmers' interest. "This gentleman had a laboratory and a room in these laboratories for some time," he wrote in his first interim report, "but he belonged to the Research Farm and eventually moved to that station". 26 Yet research with obvious economic benefits continued in the Chemical and Entomological Sections. As Chalmers was not interested in sanitary work, the post of $\mathrm{MOH}$ of Khartoum was handed to Colonel Leonard Bousfield, RAMC, the two laboratory clerks were relieved from their involvement in sanitary office work and, instead, assigned new duties in supervising the library and filing of documents. Because of lack of funds, Chalmers had to purchase, at his own expense, papers from all over the world. Now new facets of research were begun in the WTRLK, such as studies in the taxonomy of bacteria and fungi, which were made possible after provision of the required chemicals and equipment. One of the pressing research topics that Chalmers tackled was cerebrospinal meningitis. He started communications with Simon Flexner, who was then a world authority on this disease, and made arrangements to spend his leave in New York to see Flexner and the Rockefeller laboratories. Every detail was arranged for his departure from Khartoum on 25 August 1914 when the war began and all leave was cancelled. ${ }^{27}$

\section{The Laboratories During the First World War}

For most of his directorship of the WTRLK, Chalmers had to work under the adverse conditions of the First World War. Besides the difficulty of obtaining supplies, the laboratory was severely depleted of its staff. Archibald was called to serve in the Dardanelles during the Gallipoli campaign. O'Farrell, Protozoologist and Assistant Bacteriologist, together with MacDonald the Laboratory Assistant were called up for war duty in Egypt. O'Farrell, captured by the Turks in Sinai in April 1916, was held as a prisoner of war for two years, after which he resigned his post in the WTRLK. In spite of the shortage of staff, the routine work increased tremendously, especially in the Bacteriology Section. Work hours extended from 7 a.m. to about 2 p.m. and from 6 p.m. to about 7.30 or 8 p.m., seven days a week. Soon the senior assistant, Alexander Marshall, contracted typhoid and had to be sick-listed for eight months. The work load increased yet more as a result of a severe outbreak of cerebrospinal meningitis. During his investigation of this, Chalmers had the misfortune to prick his right thumb with a contaminated needle. His hand was infected and, in addition, for a long time he had to cope on his own with the work in the Bacteriology Section. Moreover, he had to cover the Entomology Section also when Harold King, who was in charge, fell sick. Chalmers was extremely frustrated that his appeals for help were not responded to by Balfour, who was then a Lieutenant-Colonel and member of the Medical Advisory Committee to the Mediterranean Expeditionary Force. Chalmers communicated his grievance to Wingate:

Recently we had to do about 100 routine examinations daily which if continued for 18 days would exceed the routine work performed by the bacteriological section of the laboratories in the 31 months which elapsed between the 3rd and 4th report issued by Balfour ... .

I do not think that it is necessary or advisable [Chalmers' emphasis] for Archibald to be kept there indefinitely doing mere routine work and I ask that it may be made clear that his services will be

26 Chalmers, GMCK, Report for 1912, p. 26.

27 Chalmers to Wingate, 25/2/1915, SAD 194/2/171. 


\section{Ahmed Awad Abdel-Hameed}

required here as soon as he has set matters going. It also seems to me that it is necessary to recall O'Farrell and MacDonald one very shortly and the other after a little time ... ${ }^{28}$

This view was supported by Archibald himself who wrote to Chalmers about his work at the front:

I realize fully all that you say $\&$ all the difficulties you have had but I want you to feel that it was no wish of mine to stay away when I know how hard pressed you were $\&$ how much you required ... I have been here a mere puppet $\&$ being only a Captain had no say in things $\&$ in fact had no idea of what was taking place. ${ }^{29}$

Balfour, on the other hand, thought otherwise as shown by his dramatic response when Wingate recalled Archibald:

The order for Archibald's recall came like a veritable bombshell, upsetting not only the Military Medical Authorities but also the Committee of which I am a member. So seriously did we regard the matter that I took the liberty of sending you a cable forthwith which I earnestly trust may have the desired effect. ${ }^{30}$

Balfour's message did have the desired effect. Archibald's recall was cancelled and Wingate had to write an apologetic message to Chalmers:

I do not think that Balfour, in spite of all his experience in the Khartoum Laboratories, quite appreciates the enormous strain on your resources and yourself personally, but on the other hand I know that you will willingly strain every nerve to help in the great cause of preventing the spread of epidemic disease amongst our troops in the Dardanelles, and at the same time I felt sure that in asking you to spare Archibald's services you would unhesitatingly make this sacrifice and would do all you could to help your old friend and predecessor. ${ }^{31}$

Perhaps one reason for Balfour's reaction was that Chalmers' publications continued to appear in international journals throughout the war. In another communication to Wingate, Balfour had this to say:

Believe me, I quite appreciate the circumstances but what I feel is that at a time like the present all research [Balfour's emphasis] work except such as is intimately connected with the war should come to an end, at least where, if carried on, it would keep a worker from war service. ${ }^{32}$

When the First World War was over in November 1918, many were gratified by the medals, clasps or brass stars given in recognition of their suffering. Chalmers was probably more satisfied by the statistics he included in his annual report for that year:

The great increase in this work during the war years, 1914-1918 inclusive (over 14,000 examinations), has thrown such an amount of continuous microscopical work on Major Archibald and myself that that eye, which we use mostly for this purpose, has become strained, but this is one of the outcomes of war conditions. ${ }^{33}$

28 Chalmers to Wingate, 23/6/1915, SAD 195/4/239-241.

29 Archibald to Chalmers, 2-31/1/1916, SAD 199/1/213-215.

30 Balfour to Wingate, 18/9/1915, SAD 196/3/219-220.

\footnotetext{
31 Wingate to Chalmers, $6 / 10 / 1915$, SAD 197/1/56-57.

32 Balfour to Wingate, Wellcome Archive, CMAC, Wellcome Institute, London.

33 Chalmers, GMCK, Report for 1918, p. 18.
} 


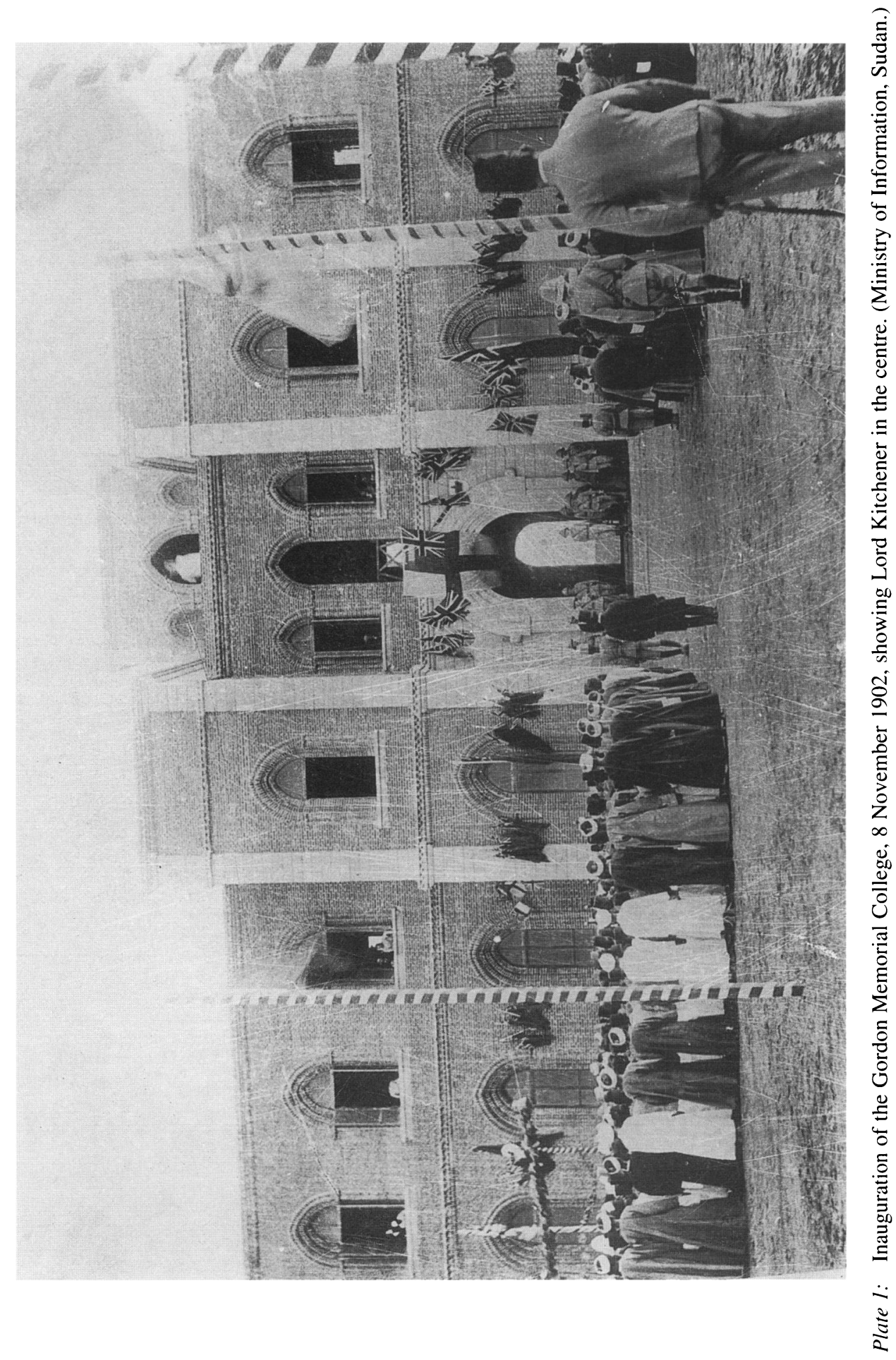




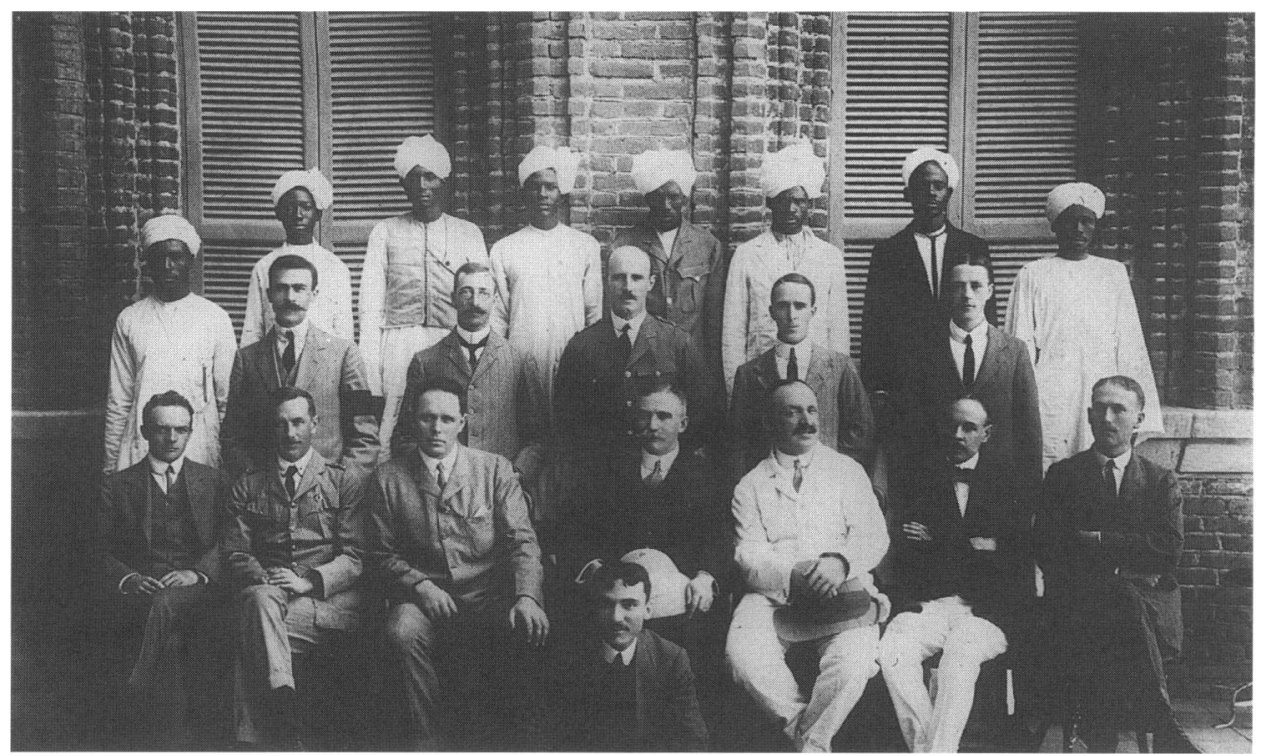

Plate 2: Henry Wellcome and the staff of the Wellcome Tropical Research Laboratories in Khartoum, 1910. Front row (from left to right): Dr J Thompson (Senior Assistant Chemist), Captain W B Fry (Pathologist and Assistant Bacteriologist), Dr Andrew Balfour (Director), Henry Wellcome, James Currie (Director of Education, Sudan Government), Dr William Beam (Research Chemist), Harold H King (Entomologist). Middle row: G G Vitale (Senior Clerk), J A Goodson (Assistant Chemist), Captain R G Archibald (Pathologist and Assistant Bacteriologist), G M Buchanan (Senior Laboratory Assistant), Mr Alex Marshall (Junior Laboratory Assistant). Back row: Sudanese laboratory attendants.

Sitting on the ground in front: Nicola Eff. Hakim (Junior Clerk). (Wellcome Institute Library, London.)

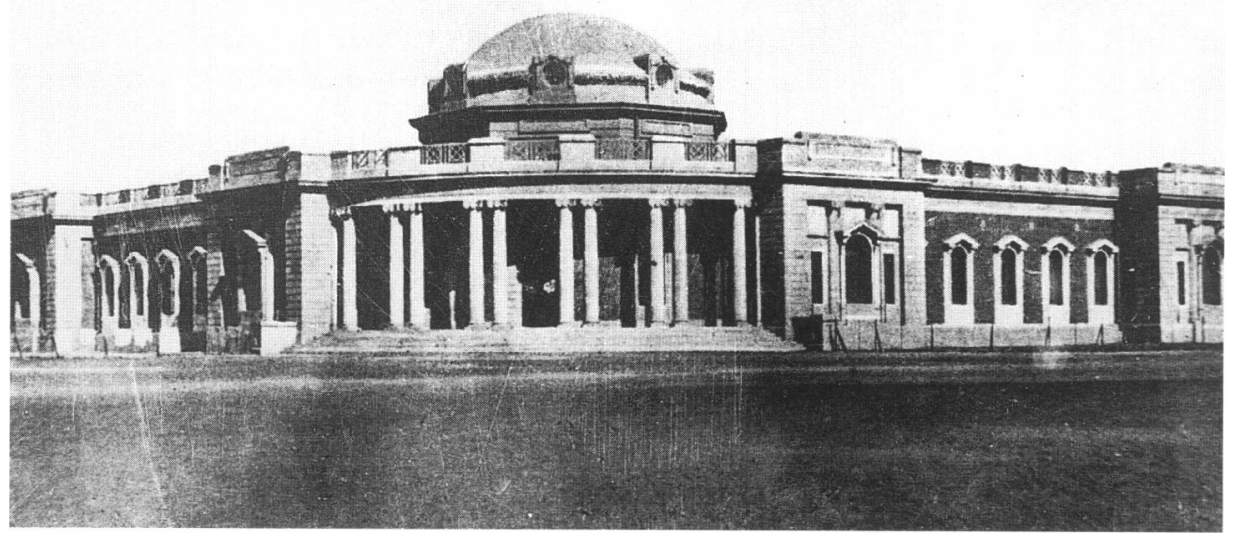

Plate 3: Lord Kitchener School of Medicine, 1924. (Ministry of Information, Sudan.) 


\section{The Wellcome Tropical Research Laboratories in Khartoum}

Yet every cloud has a silver lining. In medical research, as a result of the war, there was a better appreciation of the significance of work on communicable diseases and sanitation. In his third edition of the Manual of tropical medicine, which appeared in 1919, Chalmers alluded to this:

... still there is a great field for research, and one of the direct blessings of the recent war will be the stirring up of Governments to provide funds for this work, which should never be left, as it used to be, entirely or almost entirely to individual generosity. ${ }^{34}$

\section{Research Work Under Chalmers}

In spite of all the difficulties, the Bacteriological Section under Chalmers produced 71 publications by December 1917. Chalmers' own research concentrated on the taxonomy and pathogenicity of bacteria and fungi but he also worked on miscellaneous dermatological disorders and on sleeping sickness. His papers reflect a wide range of knowledge and deep understanding of the topics he was covering. The work he did on the classification of pathogenic fungi was widely recognized. He tried different preparations of vaccines for cerebrospinal meningitis but with the technology available at the time he could not produce a potent vaccine. Chalmers' papers reflect the tremendous effort exerted in their production. Typically he would start with an exhaustive historical account and a comprehensive review of the literature in which he frequently quoted non-English works in their original languages. A notable feature of his research was that he involved his junior staff. Perhaps this is what made Archibald write to him from the Dardanelles: "My heart is in that country \& I feel my work is too \& I want to return \& do some work with you \& for you." 35

It seemed that Chalmers never forgot his role as mentor even in the darkest hours. When O'Farrell was a prisoner-of-war in Turkey he wrote to Balfour asking for some drugs and medical comforts, and mentioned that, "Chalmers is I believe sending me out some reprints and a book on immunity, which will be pretty heavy reading for the Censor but it will be good to get it as there is plenty of time here." 36

\section{Chalmers' Resignation}

Chalmers was a passionate book collector and a capable author. One of the main things that attracted him to work in the WTRLK was the series of magnificently produced reports issued by the laboratories and edited by Balfour between 1904 and 1911. However, after a few months in Khartoum he was disappointed to realize that there were no permanent arrangements for the publication of further reports. In his interim report for 1913 he wrote:

This question is now becoming serious as no full report has been published since 1911 and a large mass of material has been collected and is more or less ready for publication. The life of the laboratory depends upon its publications, and unless either a full report is published shortly or a

\footnotetext{
34 A Castellani and A J Chalmers, Manual of tropical medicine, 3rd ed., London, Baillière, Tindall \& Cox, 1919.

35 Archibald to Chalmers, 2-31/1/1916, SAD 199/1/213-215.
}

\section{O'Farrell to Balfour, 1/11/1916, Wellcome} Archives, CMAC, Wellcome Institute, London. 


\section{Ahmed Awad Abdel-Hameed}

series of bulletins organised, the position which Dr Balfour made for the laboratory in the scientific world cannot possibly be maintained. ${ }^{37}$

When he failed to get a response, Chalmers, apparently, revealed his intention to resign. It is also apparent that Balfour learnt of this and wrote a confidential letter to Wingate warning him about Chalmers' impending resignation and the reasons for it. Wingate responded with the following letter:

My dear Balfour,

I should have written to you some time ago in reply to your Private and Confidential letter of April 13th, but a good many inquiries were necessary, all of which took time, and previous correspondence had to be looked up, and I found it was considerably distributed amongst various offices and it required careful manipulation to unearth it without giving away reasons for my inquiries. Perhaps the most difficult was my inquiry from Chalmers himself, who of course, as you know, is doing admirable work and whom I am most anxious to assist in every way. Indeed nothing would grieve me more than that he should feel that the arrangements we were prepared to make in the Sudan for the proper publication of the magnificent results the Wellcome Research Laboratories have obtained and continue to obtain in the Sudan as to make it impossible for him to continue his service in this country. I think you are well aware of my own sentiments in this matter and how much I regretted the unfortunate turn of events. Unfortunately at the present time, with our finances as they are and with all the upset in our arrangements caused by the war, I really do not believe that either by hook or crook we could screw out of the Financial Secretary $£ 500$, but I am equally certain that as soon as the great stringency is over, we shall be able to make an annual contribution of this sort, and I see that it was foreshadowed as being possible in 1915, and it certainly would have been forthcoming had not this unfortunate war broken out. My idea would therefore be for you to confidentially sound Mr Wellcome as to whether he would be prepared to renew his very generous offer, provided that the Sudan Government guaranteed $£ 500$ a year when the war is over. Of course this does not meet the immediate emergency, that is, how to provide funds for the publication at once of a report on the old lines, for I feel that unless such a publication is undertaken without delay, Chalmers may give effect to his threatened resignation.

I may mention that he has said nothing about this to me, but I expect that your information on this matter is probably correct. Can you make any suggestion as to how to get over the present difficulty for, as far as I can see, there is absolutely no possibility of raising the wind until the war is over, much as I should like to be able to do so. ${ }^{38}$

This plan did not materialize, but Chalmers seems to have been persuaded to defer pressing for publication of the reports till the war came to an end, as he indicated in his annual report (which he insisted on calling an interim report) for 1915: "The question of the publication of a full report has been shelved sine die because of the war, and we are attempting to make known our work by means of bulletins and reprints". 39 Yet again he renewed his demand for publication of reports in his annual report for 1916:

The question of a full report on the lines of the four published by Lt.-Colonel Andrew Balfour, C.M.G., R.A.M.C., is becoming more pressing as we have received inquiries with regard to this matter from the Medical Officers attached to one of His Majesty's Expeditionary Forces, and there seems to be no doubt that the knowledge acquired by the Laboratory during the last five years would be rendered much more accessible if collected in two or three volumes rather than, as at present,

37 Chalmers, GMCK, Report for 1913 , p. 18.
38 Wingate to Balfour, 26/5/1915, SAD

39 Chalmers, GMCK, Report for 1915, p. 17.

195/2/168-169. 


\section{The Wellcome Tropical Research Laboratories in Khartoum}

scattered through medical, chemical and entomological literature. It is earnestly hoped that some arrangement will be made so that a report can be published as quickly as possible when the war is over, as the laboratory is characterized by being one of the few in His Majesty's dominions which since the war began has not been supplied with the facilities for publishing a single report. ${ }^{40}$

Again, the problem was touched on in the report for 1917: "The question of a full report, as indicated in last year's interim report, is being made the subject of a special communication, and will be considered again in the interim report for 1918". In the report for 1918, Chalmers almost said that he had waited long enough:

The question of a full report will be urgently brought forward during 1919, as by 1920 no such report will have appeared for upwards of nine years, owing to lack of funds but not lack of material. While the war was in existence, no such report could be produced. Now that it is evident that the European war will finish some time in the present year, it is obvious that, failing some good reason, the extraordinary amount of material gathered together by the Bacteriological and Entomological staff should be utilised to produce two or three volumes, one containing the enquiries into the diseases of the Sudan, the second into Entomological problems, while a third might contain Botanical and Chemical reports. As usual, during 1918, the Laboratories continued to be in touch with British, Allied and Neutral Institutions throughout the world, but recently a number of enquiries have been made as to the date when a report may be expected from these Laboratories. ${ }^{41}$

In the middle of February 1920, Chalmers submitted his resignation to the Sudan Government and set out with his wife on a well-earned leave to be spent on a round-theworld journey but he fell ill in India. He died of acute infective jaundice in the General Hospital at Calcutta on 5 April 1920.

\section{The Chalmers Medal}

In the early years of this century, life in the Sudan was particularly hard for the wives of British officials. There were few British women in a society centred on club life. Most were led to accept this hardship by an awareness that "one was part of a world-wide British Empire and in some way privileged to be part of it". ${ }^{42}$ Chalmers' wife had, in addition, an awareness that she was a partner in her husband's strenuous effort to make lasting contributions to medicine and science. For this reason she was particularly keen to see his efforts recognized. A short time after Chalmers' death, a favourable review of the third edition of the Manual of tropical medicine co-authored by Castellani and Chalmers was published in the Journal of Parasitology. ${ }^{43}$ Balfour sent a copy to Alice Chalmers. She replied expressing her satisfaction with the review, but saying that she was very upset that her husband was not given due credit:

Why the Reviewer should describe my husband as "the junior author", I fail to understand. In age he was senior by $41 / 2$ years, and I think had held just as important titles. It was my husband, and not Dr Castellani, whom the publishers asked to write the book for them, \& it was he who invited Dr Castellani to collaborate with him, not vice versa. And I think it is an open secret that my husband did the larger share of the work. As every word of the M.S.S of the first edition passed through my hands, I could pretty well judge. Of course, Dr Castellani's name is more widely known in continental

40 Chalmers, GMCK, Report for 1916, p. 15.

42 C Allen (ed.), Tales from the dark continent,

41 Chalmers, GMCK, Report for 1917, p. 12; ibid, 1918 , p. 17.

London, MacDonald Futura, 1979, p. 130.

43 Anon., book review, J. Parasitol, 1920, 7:50-3. 


\section{Ahmed Awad Abdel-Hameed}

countries, owing to his having discovered the Sleeping Sickness germ, but as regards the writing of the Manual, it is quite wrong that my husband should be regarded as his understudy. I always argued with him that it was ridiculous to put Dr Castellani's name before his own, but he would do it \& now his name is to go down to memory as Dr Castellani's satellite, which he certainly was not. ${ }^{44}$

To ensure that her husband received proper recognition, she wrote to members of the Royal Society of Tropical Medicine and to Sir James Cantlie, President of the Society, to make sure that an appropriate obituary of her husband was written. She was particularly anxious that his work in the Sudan should be made known. In a letter to Balfour she wrote:

As regards our 10 years in Ceylon, there has been a very well-written \& accurate account in the journal of the Ceylon Branch of the B.M.A. This might almost be embodied in toto \& would save Sir James the trouble of considering the history of those 10 years. With regard to our 7 years in the Sudan, it seems to me that, owing to the disagreement between Mr Wellcome \& the Sudan Government, there is going to be absolutely no record at all of my husband's 7 years of strenuous work, \& the work he encouraged others to do with him at the Laboratories in Khartoum. It is of course impossible for Sir James to ascertain details of these 7 years, and I thought it might be a good idea if Major Archibald were asked to write a short account for Sir James to use. And also, I thought there might be a complete list, at the end of the publication, of the numerous original papers which my husband either wrote entirely himself, or encouraged his helpers to write with him, during those 7 years. This would make a useful list for reference. Otherwise it seems to me his original work of the last 7 years will be lost in oblivion. . . ${ }^{45}$

She also donated his library to the Royal Society of Medicine. The British Medical Journal described it as probably the finest collection of books on tropical medicine to be found anywhere. In addition, Mrs Chalmers donated $£ 500$ to pay for shelving and furnishing a room to house it, and it was called "The Chalmers Library". Unfortunately these books were distributed among other collections afterwards. Perhaps the most effective method by which Alice Chalmers perpetuated the memory of her husband was by donating $£ 500$ to the Royal Society of Tropical Medicine and Hygiene to create a
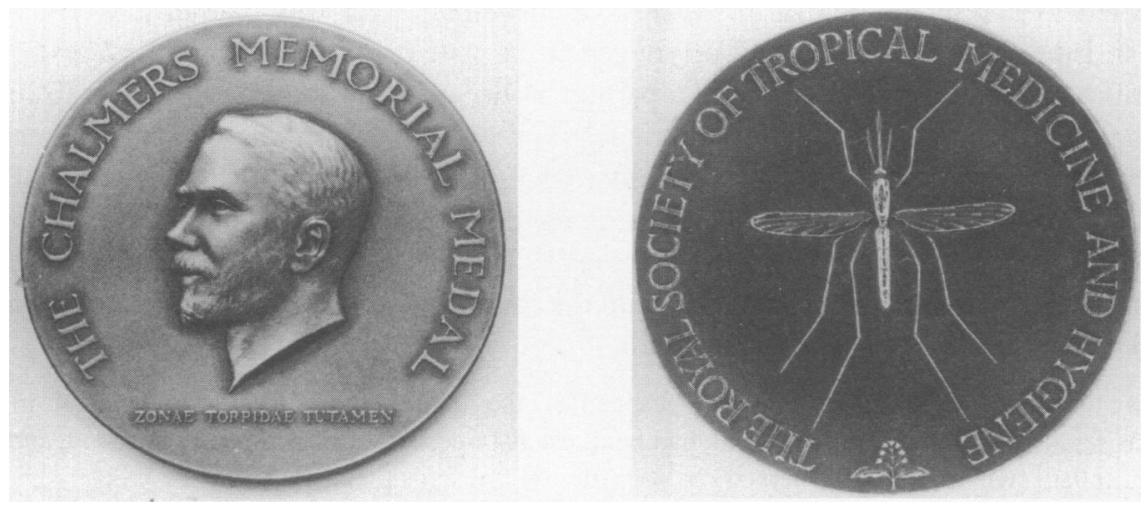

Figure 1: The Chalmers Medal. (Royal Society of Tropical Medicine and Hygiene archives, CMAC, Wellcome Institute, London.)

44 Alice Chalmers to Balfour, 31/10/1920, Wellcome Archives, CMAC, Wellcome Institute, London.

45 Alice Chalmers to Balfour, 20/1/1921, Royal
Society of Tropical Medicine and Hygiene archives, CMAC, Wellcome Institute, London, WTI/RST/A.15. 


\section{The Wellcome Tropical Research Laboratories in Khartoum}

medal in his name. At first she was not satisfied with the inscription proposed by the Society: Zonae torridae tutamen. The motto implies that the medal rewards achievement in the field of health in the tropics, whereas Alice Chalmers wanted her husband's work to be viewed as more universal, contributing to advances in medicine and science. ${ }^{46}$ However, after Wenyon wrote explaining the Society's view of this matter she agreed wholeheartedly:

Of course I agree with you that altruism is, or should be, at the base of all medical research work, not merely the advance of Science in the abstract. What I meant to indicate, though I am afraid I cannot have expressed myself very clearly was, if I may adapt the well-known couplet: "Races are many, but Health is one, And includes them all . ..."47

The Chalmers Memorial Medal is now one of the most prestigious awards offered by the Royal Society of Tropical Medicine and Hygiene every year in recognition of outstanding research contributing to knowledge of tropical medicine and tropical hygiene. To recognize Chalmers' great interest in the work of young people, the medal is restricted to persons forty-five years of age or younger on 1 June of each year. The medal, which is in silver gilt, bears Chalmers' likeness over the motto Zonae torridae tutamen on the obverse and on the reverse a representation of Anopheles gambiae above a spray of the cinchona plant and encircled by the name of the Society.

\section{IV}

\section{Sir Robert Archibald: The Years of Harvest}

The time when the prophets of research had to clamour for a hearing are happily over $\ldots{ }^{48}$

Robert George Archibald was born in Secunderabad, India, on 4 July 1880 . He graduated from Edinburgh with MB, ChB in 1902. After hospital appointments in Britain, he joined the Royal Army Medical Corps in 1906, winning the prize in pathology at the Army Medical College at Millbank in that year. He worked for a year in Colonel (later Sir) William Leishman's laboratory before gaining the Sleeping Sickness Commission in Uganda headed by Colonel (later Sir) David Bruce. After spending an eventful period in Uganda, he was transferred to the Sudan in 1908 as regimental medical officer and at the same time he held the post of Assistant Bacteriologist and Pathologist in the Wellcome Tropical Research Laboratories in Khartoum under Andrew Balfour.

Balfour found in Archibald a hard-working and capable scientist who assisted him in the laboratory work and in producing the voluminous "Reviews". A strong working relationship developed between them, as Balfour's desire to have Archibald by his side in the Mediterranean during the First World War indicated. Later on, Archibald also won the admiration of Chalmers, who wrote: "We understand each other very well and think alike on many matters professional \& otherwise". 49

Archibald was a handsome and imposing Scot, a typical sportsman with a pleasant and friendly character. He extended his friendship to Sudanese staff in the laboratory as well

46 Ibid.

47 Alice Chalmers to Wenyon, 16/5/1921, Royal Society of Tropical Medicine and Hygiene archives,
CMAC, Wellcome Institute, London, WTI/RST/A.15.

48 Crowfoot (ed.), GMCK, Report for 1920 , p. 20.

49 Chalmers to Wingate 3/7/1915, SAD 196/1/95. 
as to British officials, who held him in great respect. Early in his career he travelled extensively in the Sudan, learnt Arabic, acquired insight into the Sudanese people and developed a strong attachment to their country. In a letter to Chalmers written from the Dardanelles he stated: "My heart is in that country and I feel my work is too". 50 This explains his motivation to spend a lifetime in devoted service that left a lasting impact on the country and on tropical medicine.

In 1920 Robert Archibald succeeded Chalmers as director of the WTRLK. By this time, the laboratories were already in the forefront of tropical disease research at the international level. In the Sudan the laboratories assumed a leading role in the post-war economic development. Archibald's directorship was characterized by immense activity, rapid expansion of the laboratory services to cover the whole country, and close collaboration with other government departments in research. His work was recognized by a knighthood conferred on him in 1934; he was the only doctor to receive the accolade while still in the Sudan service.

\section{Expansion: Reaching for the Provinces and Decentralization}

After the First World War the WTRLK underwent a huge expansion to meet increasing demands of the health services and agricultural projects. Once the vacancies caused by the war were filled, new posts were created, so that in 1920 the laboratories were employing 16 British staff out of a total of 31 in the entire Education Department. Laboratory assistants were recruited from graduates of the Gordon College High School.

There was a steady increase in the volume of routine pathology tests handled by the Bacteriology Section because of the development of the peripheral health care system. Unlike his predecessors who saw involvement in routine tests as a diversion from research, Archibald advocated applied research based on these routine tests. He was delighted by the ever-increasing load of such work, especially of specimens sent from outstations. In this way he built up strong collaboration with medical officers. In his annual report for 1921, he wrote:

It might well be said that the time occupied by routine examinations interferes greatly with research. This may be so, but at the same time it should be realized that routine work begets research. Past experience has shown that medical officers are not slow in sending material for research in return for routine examinations satisfactorily carried out. . . During the past twelve months a closer cooperation has been maintained with the medical officers of the Civil Hospitals than has existed in the previous years, such collaboration bids fair to be beneficial not only to both parties concerned, but to the cause of science generally. ${ }^{51}$

In 1928 the Bacteriological Section was moved to the Stack Memorial Laboratories, which were opened near Khartoum Civil Hospital and the Kitchener School of Medicine. The new buildings allowed greater expansion in the bacteriology services and easy access to hospital patients. A small pathology laboratory was also opened in Omdurman to serve the Omdurman hospital.

50 Archibald to Chalmers, 2-31/1/1916, SAD 199/1/213-215.
51 Archibald, GMCK, Report for 1921, pp.19-20. 


\section{The Wellcome Tropical Research Laboratories in Khartoum}

Early in his directorship, Archibald proposed a long-term policy of decentralization of laboratory services by building regional laboratories in the Sudanese provinces which would carry out medical, entomological and chemical investigations. Before funds were available to erect such laboratories, he encouraged, as a short-term measure, visits to outstations by members of the staff to acquire knowledge of field conditions. These visits brought the laboratories closer to other government departments and oriented their research towards the local problems seen there. Archibald himself visited every province in the Sudan. He studied meningitis and kala-azar in the East, sleeping sickness in the south, bilharzia and tsetse flies in the Nuba Mountains in the west and bilharzia in Dongola Province in the north. He conducted these visits as multidisciplinary research tours that covered many aspects of a particular area. For example, in his report on the Nuba Mountains Province he listed the objectives of the visit as:

(1) To ascertain the existence of bilharziasis in the districts traversed. (2) to obtain the intermediate molluscan hosts. (3) to study the natural conditions under which these intermediate hosts existed with view of preventive measures being carried out. (4) to locate the existence and habitat of the Tsetse fly in Koalib Hills. (5) in conjunction with the Govt. Entomologist to examine cotton for the presence of pests and obtain further information regarding certain habits of the cotton stainer bug. ${ }^{52}$

On his way to the Nuba Mountains he reported on public health matters ranging from mosquito wiring in government houses and their ventilation, to inventories of sera available in the hospitals. In 1927 a Railway Laboratory Car was fitted for medical research in out-stations. It soon proved its value. In 1928 it was requisitioned on twentyeight occasions. Among its different uses, this car made possible regular bacteriological examination of water supplies from the main towns in the Sudan connected by rail. Regional laboratories were established in Wad Medani, Port Sudan, Atbara and Berber.

\section{Economic Development, Epidemics, and Publications}

The post-war economic boom in the Sudan resulted in a great expansion in agriculture and railways. Archibald himself made numerous studies on diseases of cotton. Besides its routine duties, the Chemical Section became involved in planning big agricultural and construction projects. Tests were done on the building materials used for dams and other government buildings. By 1928 a soil survey was completed that included chemical analysis of samples covering three million feddans ( 1 Sudanese feddan $=1.038$ acres) intended for the cultivation of cotton. In Atbara, where the main Sudan Railways workshops were located, a small laboratory was opened which tested fuel and oil lubricants, the calorific value of coals, analysed metals and alloys, and undertook regular examination of samples of boiler water brought from different railway stations. The Entomology Section covered a variety of fields: surveys for insect vectors of human and animal diseases, control of migratory locusts and other plant pests, and experiments in breeding honey bees and silkworms. Control of locusts required extensive operations in different parts of the country. Harold King, the entomologist who co-ordinated all this work from the WTRLK, was thus nicknamed "the King of Locusts". All this work

52 R G Archibald, 'Notes regarding visit to the Nuba Mountains Province 25th December, 1926', unpublished document, The Central Laboratory, Khartoum. 
required immense activity in the regional laboratories and the training of Sudanese laboratory assistants, some of whom were soon put in charge of these laboratories. This section gathered a valuable collection of insects of medical and economic importance, which was classified with the help of the British Museum, and included numerous species new to science.

With improved communications and the development of peripheral health services, epidemics in remote areas that used to pass unnoticed by the authorities in Khartoum were now brought under scrutiny. The country was under constant threat from outbreaks of disease not only within the Sudan but also in neighbouring African states that did little to prevent the spread of diseases across their borders. ${ }^{53}$ Relapsing fever spread unchecked from West Africa into the western province of Darfur, sleeping sickness reached the southern Sudan from the Congo and Uganda, kala-azar invaded from Ethiopia in the east, and from the north there was a continuous influx of agricultural workers with schistosomiasis and intestinal parasites. The WTRLK offered great services in controlling these epidemics, sometimes using unconventional methods. When an outbreak of relapsing fever occurred in Darfur province in the western Sudan, the Senior Medical Officer wired Khartoum and asked for the help of a pathologist to settle the identity of the intermediate host:

Dr Riding was sent from the Wellcome Laboratory armed with a box of fifty white rats: forty-nine of them were killed en route by exhaust fumes. Fortunately Riding's Sudanese cook developed relapsing fever on the way and the surviving rat could be inoculated, but next night, having survived the perils of a thousand-mile journey, the rat escaped in a DC [District Commissioner] house and disappeared down a hole, much to the consternation of the inhabitants. Riding rose to the occasion and placed suspect lice in a test tube kept warm by his body heat, and in due course demonstrated the spirochaete recurrentis in them and confirmed the disease as the louse-borne variety. ${ }^{54}$

Captain Spence, Assistant Bacteriologist, established a quarantine base in Halfa on the Sudan-Egypt borders to examine Egyptian agricultural workers brought in to work on the irrigation schemes in central Sudan. These labourers were mainly tested for bilharzia. In $1920,16,500$ labourers were screened, and in the following year anthelminthic treatment was accompanied by louse disinfestation for all those coming in. This work offered an opportunity to carry out investigations on intestinal parasites. The laboratories also started to produce large quantities of vaccines, especially for rabies, cholera, and for local strains of typhoid and paratyphoid. Vaccination campaigns were organized for groups at risk such as soldiers and pilgrims.

During his directorship, Archibald authored or co-authored more than forty original research papers on the epidemiology, pathology, therapeutics, parasitology and mycology of tropical diseases of humans and animals. He also published original research on the diseases of cotton. The Entomology and Chemical Sections had articles published in international journals, in the local Sudan Notes and Records and in Bulletins issued by the WTRLK. A notable publication edited by Archibald with W Byam was The practice of medicine in the tropics. ${ }^{55}$ This authoritative compendium in three volumes covered not

53 A Cruikshank, 'The golden age of tropical medicine and its impact on the modernization of the Sudan', in M W Daly (ed.), Modernization in the Sudan, New York, Lilian Barber Press, 1985, pp. 92-100.

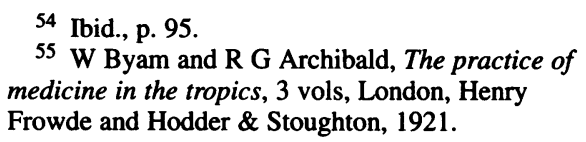
medicine in the tropics, 3 vols, London, Henry Frowde and Hodder \& Stoughton, 1921. 
only tropical diseases but also certain diseases not peculiar to the tropics but having special features in tropical countries. The book also included chapters on nursing, the diseases of women, water analysis, preparation of vaccines and laboratory techniques.

\section{The Kitchener Memorial School of Medicine}

On his last visit to the Sudan in 1911, Kitchener put forward the idea of establishing a medical school to train doctors within the country. The need for such a school became even more pressing during the First World War when the supply of Syrian doctors on whom the medical services in the Sudan were heavily dependent was shut off. After Kitchener's death in 1916, Wingate appealed for a medical school to be built as a memorial to him. The project was delayed by the war and the high prices of building materials, but by 1923 construction of the buildings was already under way. The authorities were encouraged by the fact that most of the requirements of the medical school were already available in the WTRLK as Wingate pointed out in his capacity as Chairman of the Gordon Memorial College Trust:

The way, it is true had been paved by the successful scientific research work undertaken by the well-equipped Wellcome Research Laboratories and consulting rooms where a staff of bacteriological and medical experts have for years been engaged in examining problems of tropical vegetation, germ-life and disease. . . Conditions therefore were entirely favourable for establishment of a Medical School. ${ }^{56}$

In 29 February 1924 the Kitchener School of Medicine was inaugurated. It was built by private subscription from the United Kingdom and the Sudan and donations from the British Red Cross and the Sudan Government. The School was the first of its kind in North Africa since the founding of Kasr al-Aini in Cairo one hundred years earlier. Most of the teaching was carried out by staff of the WTRLK who lectured on bacteriology, pathology, physiology, and, in addition, conducted post-mortems for teaching purposes. In 1928 seven fully qualified Sudanese doctors graduated from the school.

It was a red letter day for the Sudan, and also for their British teachers, all but one of whom were government officials ... It was the cheapest medical school ever, consistent with quality . . In 1934 the number of Sudanese doctors had exceeded the British for the first time: Sudanese forty-eight, British forty, and Lebanese fourteen. Within three years Sudanese doctors were being promoted to senior posts, and numbers had obtained higher degrees and became specialists. ${ }^{57}$

\section{Dismemberment of the WTRLK}

In the early 1930s the Sudan was hit by severe recession; salaries of government employees were reduced and the services of others, including workers in the WTRLK, terminated. The laboratories lost some of their best scientists. In the Entomology Section Harold King retired after twenty-six years of distinguished service. Alex Marshall, the superintendent in bacteriology, also retired after twenty-two years of service. The laboratories were too deeply rooted to be wiped out by the financial crisis. Yet, their unique identity came under attack by the new authorities in the Sudan for a variety of

\footnotetext{
56 Wingate, GMCK, Report for 1922, p. 6.
}

57 Cruikshank, op. cit., note 53 above, pp. 90-1. 


\section{Ahmed Awad Abdel-Hameed}

reasons. Political and administrative changes in the country brought about new perceptions and policies that had direct bearing on the WTRLK. Although, at the beginning, professionals were in charge of education in the Sudan, later Governors appointed political officers to head the Department of Education. R F Winter, appointed in 1932, remained director when the Governor Sir Stewart Symes suppressed that department in $1934 .{ }^{58}$ As part of this suppression, the different units of the WTRLK were distributed among other government departments. This was done against the wishes of Sir Henry Wellcome, who saw in the new arrangement a departure from the original conditions on which he had donated the laboratories. One reason given for dismembering the laboratories was that the Department of Education needed the space occupied by the WTRLK in the Gordon Memorial College. Wellcome offered to build and present to the Government new laboratories at a cost of over $£ 60,000$. With his usual perfectionism, he insisted on a first-class river-front site to fit the magnificent building. When the Government insisted on another site the offer was withdrawn.

Dismemberment of the WTRLK was completed in 1935. Wellcome's name was preserved in a small chemical unit which was named 'The Wellcome Chemical Laboratories'. One year later, on 25 July 1936, Sir Henry Wellcome passed away peacefully after an operation at the London Clinic, at the age of eighty-two. In his will he had made a generous conditional offer to the Khartoum laboratories in a section which read:

... AND I AUTHORISE my Trustees out of the Research Fund to make grants after the first five years after my death of a sum not exceeding Two Thousand Pounds a year and after ten years after my death of a sum not exceeding Three Thousand Pounds a year for the Trustees of the Gordon Memorial College at Khartoum under supervision of such Trustees in conjunction with the Government of the Sudan for the exclusive use of the Wellcome Tropical Research Laboratories at the Gordon College for so long only as such Laboratories shall be conducted on the lines and for the purposes indicated in my letter of gift of the said laboratories dated the twenty-eighth day of September One thousand nine hundred and one addressed by me to the Governor General of the Anglo Egyptian Sudan and accepted by him in writing and so long only as conditions of such letter of gift are observed by the said Trustees and the Sudan Government and that the said Government fully maintains and supports with an adequate and efficient staff the said Laboratories for the purpose indicated in the letter of gift and so long only as such Laboratories shall bear and be called by the official name of "The Wellcome Tropical Research Laboratories" which name was given to them by the express desire and direction of the Sudan Government and the Trustees of the Gordon Memorial College Khartoum and to be used exclusively for the purpose of providing the cost of the publication of Reports similar to the Reports issued at my expense from these Laboratories and edited by Dr Andrew Balfour during his Directorship recording the new and original research and other work conducted by The Wellcome Tropical Research Laboratories at Khartoum and in the auxiliary Wellcome Floating Research Laboratories on the River Nile and its tributaries or elsewhere or during land expeditions by caravan or otherwise to the outlying regions whether such work is done by the permanent or auxiliary staff . . ${ }^{59}$

A case was put forward that the Wellcome Tropical Research Laboratories still survived in the Wellcome Chemical Laboratories. This argument did not convince the Wellcome Trustees who could not accept that the survival of the name fulfilled the conditions

58 M W Dali, Imperial Sudan, Cambridge University Press, 1991, p. 105.
59 The Will of Sir Henry Wellcome, Wellcome Archives, CMAC, Wellcome Institute, London. 


\section{The Wellcome Tropical Research Laboratories in Khartoum}

stipulated in the will and the generous support offered never found its way to Khartoum.

After the dismemberment of the WTRLK, Archibald worked for two years in the Stack Memorial Laboratories which housed the Bacteriological Section of the WTRLK. In 1936 he left for the West Indies where he took charge of a leper settlement in Trinidad. At the beginning of the Second World War he returned to Dorset and worked as a pathologist and consultant in tropical medicine. In 1947 he joined the King Farouk University in Egypt as Professor of Bacteriology, becoming also Professor of Parasitology in 1949. He died suddenly at the age of seventy-two while on a visit to Salisbury, Southern Rhodesia.

\section{V \\ The WTRLK as an Experiment}

\section{Contributions of the WTRLK to Development in the Sudan}

The Wellcome Tropical Research Laboratories-housed for many years in our College at Khartoum-proved of immense value not only to the Sudan itself but to the whole world ... 60

It is evident that the WTRLK contributed to developments in a variety of fields in the Sudan, most notably in agriculture, health and higher education. The major agricultural schemes in the country today, with their research units, originated from the work of the WTRLK. With regard to the health services, Dr Leonard Bousfield, who joined the Sudan service in 1908 and continued to serve in the Sudan until well after the disappearance of the WTRLK, wrote:

It is not possible to speak too highly of the work of the Wellcome Tropical Research Laboratories at the Gordon College. Much pioneer work was accomplished here, work that was recognized by knighthoods conferred on Dr Andrew Balfour and Major Robert Archibald. The staff of the Wellcome Laboratories were always helpful to us and they did nearly all our bacteriological, pathological, chemical and entomological work. We were fortunate to have such advanced assistance in an area of such primitive conditions. ${ }^{61}$

By establishing facilities for research and training, the WTRLK accelerated the evolution of the educational system in the Sudan to a remarkable extent. Higher education in medical and agricultural sciences developed on the foundations laid by the WTRLK much more rapidly than it would have done otherwise. In this respect, Sir James Currie, who designed the master plan for the educational system in the Sudan, was right to say:

Parallel to the educational effort went the work of scientific research. It was clear that if any claim to University status as a teaching organisation was successfully to be established, such recognition would necessarily be deferred for a generation. Pending that development, however, room existed in the College to house a limited number of scientific workers, and the problems awaiting solution were many and urgent, both appertaining to problems of tropical medicine and of agricultural development. The munificence of $\mathrm{Mr} \mathrm{H}$. S. Wellcome-now Sir Henry Wellcome-rendered possible a beginning earlier than would otherwise have been the case $\ldots{ }^{62}$

60 Lord Cromer, GMCK, Report for 1936, p. 6.

61 L Bousfield, Sudan doctor, London, Christopher Johnson, 1954, p. 71.
$62 \mathrm{~J}$ Currie, 'The educational experiment in the Anglo-Egyptian Sudan, 1900-1933', J. Afr. Soc., 1935, 34: 41-59, quoted in GMCK, Report for 1936, p. 6. 


\section{Ahmed Awad Abdel-Hameed}

As the Kitchener School of Medicine opened about fifteen years before any other comparable school of higher education in the Sudan, it attracted the cream of the output of the Gordon Memorial College for many years. This enabled a smooth transition of medical services from the expatriates to Sudanese doctors. ${ }^{63}$

\section{Contributions of the WTRLK to Tropical Medicine}

The world-wide publicity given to the WTRLK and the widely publicized and magnificent laboratory reports helped dispel the impression that the "dark continent" was not habitable and that its diseases were not preventable. Great interest was created in tropical medicine, and many novel ideas in tropical medicine could be traced to the WTRLK. One such innovation was the floating laboratory. Balfour carried this idea with him when he took up his post as Director-in-Chief of the Wellcome Bureau of Scientific Research. He travelled to South America and drafted a tentative agreement in 1914 with the government of Venezuela to establish floating research laboratories on the Orinoco River. ${ }^{64}$ The outbreak of the First World War brought this project to an end. The idea of the floating laboratory led to Balfour's proposal of a marine floating medical school as a means of overcoming the difficulty of obtaining material for teaching tropical medicine in Britain. ${ }^{65}$ This instigated an extensive debate among authorities in tropical medicine. Local "shore laboratories" were suggested as an alternative. Eventually, this chain of ideas gave rise to the Calcutta School of Tropical Medicine. ${ }^{66}$

Another of the WTRLK's contributions to tropical medicine was that of collecting and classifying the literature in this field, as in the issues of Review of some of the more recent advances in tropical medicine, published in 1908 and 1911, edited by Balfour and Archibald. This publication was subsequently continued as the Tropical Diseases Bulletin produced by the Bureau of Hygiene and Tropical Medicine in London from 1913.67 Balfour was also fond of collecting and classifying, and of presenting information in museums, which he regarded as "three dimensional textbooks". One of his first acts on founding the WTRLK was to assemble a pathology museum. Immediately after his appointment as Director of the Wellcome Bureau for Scientific Research he began establishing a museum for tropical medicine. ${ }^{68}$

Success of the WTRLK in Khartoum encouraged establishment of similar institutions in other tropical areas. In 1928 a bill was proposed for the United States Government to fund the Gorgas Memorial Laboratory in Panama. The expert opinion of Henry Wellcome was sought. He gave a lengthy statement before the Committee on Foreign Affairs of the House of Representatives of the United States, covering the background and achievements of the Wellcome Tropical Research Laboratories in Khartoum, as well as the lessons learnt. He set out good reasons why such laboratories should be established in the tropics,

63 E D Pridie, 'Sudan medical services', 1924-45, unpublished document, SAD 720/7/1-159.

64 British Legation in Caracas to Balfour, 1/4/1914, Wellcome Archives, CMAC, Wellcome Institute, London.

65 A Balfour, 'A marine floating laboratory for the study of tropical medicine', Lancet, 1910, ii: 55-6.

66 G C Cook, From the Greenwich hulks to old St
Pancras: a history of tropical diseases in London, London, Athlone Press, 1992, pp. 213-14.

67 Obituary, Sir Robert G Archibald, Br. med. J., 1953, i: 1112-13.

68 A Balfour, 'The graphic method of demonstrating tropical medicine', J. trop. Med. Hyg., 1920, 23: 213-15. 


\section{The Wellcome Tropical Research Laboratories in Khartoum}

stating that they provided a research base for development in many areas, including malaria control, public health, and the promotion of scientific methods for the reclamation of land for agriculture. The Bill, without changes or amendments, was passed by the Senate and signed by the United States President. Wellcome's flair for publicity never waned. A complete account of the Hearings and the House Proceedings were included in a brochure entitled Gorgas Memorial Laboratories-research work touching causes and prevention of tropical diseases-Panama. The brochure was sponsored and published by Henry Wellcome at his own expense. ${ }^{69}$

\section{Champions of the WTRLK}

The question that must be asked is: how much did Henry Wellcome really give and how much did he benefit from the WTRLK? M Coray sees in such a question a failure to appreciate Christianity and Duty as moral values that shaped the personality of British individuals who served in the Sudan during the colonial period, which he attributes to our "ruthless search to uncover the more mercenary motives which shape present-day society".70

Yet, the humanitarian motives of businessmen and industrialists have always been questioned. This is particularly so in the pharmaceutical industry because it profits from disease and suffering, the things it is supposed to be fighting against. ${ }^{71}$ In its fight against disease, it also makes huge profits from patented vaccines. It goes without saying that without the munificence of Henry Wellcome the WTRLK would not have existed. That is not to say that Wellcome did not benefit from these laboratories. The publicity for himself and his firm was a good bargain for the $£ 15,000$ he donated to establish them, and the general impression achieved was that he was actually paying the running costs as well, whereas in fact the financial burden of the laboratories was a constant headache for the successive WTRLK directors. Even publication of the laboratory reports, paid for initially by Wellcome, was later left to the Sudan Government, which failed to produce the required sums. This led to the frustration and finally the resignation of Chalmers. Those in charge of the finances in the Sudan went to great lengths to keep the laboratories running against the odds. The budget was a heavy burden on the Department of Education. The floating laboratory, which is called the 'Wellcome Floating Laboratories' in Wellcome's will, was in fact acquired as a barge from the Sudan Government which, thanks to Currie and Balfour, also provided it with a launch. Wellcome supplied its fittings and laboratory equipment. The reiteration of these facts is not meant to belittle Wellcome's contribution but rather to set on record that there were other champions in the story of the WTRLK. The initiative, commitment and contribution of scientists and administrators in the Sudan Government were very instrumental in the success of the

\footnotetext{
69 W H Wright, 40 years of tropical medicine research: $a$ history of the Gorgas Memorial Institute of Tropical and Preventive Medicine, Inc. and the Gorgas Memorial Laboratory, Washington, printed by Reese Press, Baltimore, 1970, p. 13.

70 M S Coray, 'In the beginning', in R Collins and F Deng (eds), The British in the Sudan 1898-1956,
}

\footnotetext{
Stanford, Hoover Institution Press and Stanford University, 1984, p. 28.

71 T Tansey, 'The founding of the Wellcome Physiological Research Laboratories: conflict or concord in medical research', in Pills and profits: the selling of medicines since 1870, London, The Wellcome Trust, 1994.
} 
laboratories. Scientists like Balfour, Chalmers and Archibald could have found easier ways of pursuing careers in other institutions with more convenient circumstances and long and established traditions. Instead, they chose to spend the best years of their professional lives building a name and traditions for the WTRLK.

In Khartoum today, the magnificent red-brick buildings that used to house the Wellcome Tropical Research Laboratories still stand well preserved as part of the University of Khartoum. Through their arcades Henry Wellcome once walked and saw possibilities that others could not see. The young Dr Andrew Balfour used to come here every morning riding on a donkey, determined to accomplish a great deed such that "even a Scotsman could do no more!". Chalmers spent long hours in silent work looking down the microscope and writing his notes on classification of pathogenic fungi. In these rooms Archibald worked for twenty-six years during which he saw the laboratories grow from an auxiliary to the Gordon Memorial College to a research centre with a field of study covering the one million square miles of the Sudan. Indeed, the whole story of the Wellcome Tropical Research Laboratories in Khartoum was a big experiment with unequivocal results. 